GRASAS Y ACEITES 67 (4)

October-December 2016, e159

ISSN-L: 0017-3495

doi: http://dx.doi.org/10.3989/gya.0450161

\title{
Effect of extra virgin olive oil components on the arachidonic acid cascade, colorectal cancer and colon cancer cell proliferation*
}

\author{
C.E. Storniolo and J.J. Moreno ${ }^{\bowtie}$ \\ Department of Nutrition, Food Sciences and Gastronomy, Faculty of Pharmacy and Food Sciences, Institute of Nutrition and \\ Food Safety (INSA-UB), University of Barcelona \\ ${ }^{\square}$ Corresponding author: jjmoreno@ub.edu
}

Submitted: 18 April 2016; Accepted: 24 June 2016

\begin{abstract}
SUMMARY: The mediterranean diet (MD) reduced the risk of colorectal cancer (CRC), and olive oil, the primary source of fat in the MD, has also been found to have a protective effect. However, animals fed with oleic acid present a high number of intestinal tumours, suggesting that oleic acid and olive oil consumption can exert different effects on CRC. Considering that extra virgin olive oil (EVOO) is a complex mix of fatty acids and minor compounds such as polyphenols, hydrocarbons, phytosterols and triterpenes; and that these compounds have antioxidant activity and consequently they can modulate the arachidonic acid (AA) cascade and eicosanoid synthesis. This review analyzes the state of the art of olive oil components on the AA cascade and cellular mechanism involved in CRC such as intestinal epithelial cell growth/apoptosis, to understand the fact that the consumption of seed oils with high oleic content or EVOO will probably have different effects on CRC development.
\end{abstract}

KEYWORDS: Cell growth; Colorectal cancer; Eicosanoid; Oleic acid; Oxidative stress; Polyphenol

RESUMEN: Efecto de los componentes del aceite de oliva virgen extra en la cascada del ácido araquidónico, el cáncer colorrectal y la proliferación de células de cáncer de colon. La dieta Mediterranea (DM) y el aceite de oliva reducen el riesgo de cáncer colorrectal (CCR). Sin embargo, animales alimentados con dietas ricas en ácido oleico presentan un elevado número de tumores intestinales, lo que sugiere que el consumo de ácido oleico y aceite de oliva pueden tener efectos diferentes sobre el desarrollo de CCR. Considerando que el aceite de oliva extra virgen (AOEV) es una compleja mezcla de ácidos grasos y compuestos minoritarios como polifenoles, lignanos, hidrocarburos, fitoesteroles y triterpenos; y que algunos de estos compuestos son antioxidantes y modulan la cascada del ácido araquidónico (AA) y la producción de eicosanoides. Analizamos la información existente sobre el efecto de los componentes del AOEV sobre la cascada del AA y los mecanismos implicados en el CCR como el crecimiento de las células epiteliales intestinales/apoptosis, lo que nos permitirá entender por qué el consumo de aceites de semillas altos en oleico o AOEV probablemente tendrán diferentes efectos sobre el desarrollo del CCR.

PALABRAS CLAVE: Ácido oleico; Cáncer colorrectal; Crecimiento celular; Eicosanoide; Estrés oxidativo; Polifenol

Citation/Cómo citar este artículo: Storniolo CE, Moreno. JJ. 2016. Effect of extra virgin olive oil components on arachidonic acid cascade, colorectal cancer and colon cancer cell proliferation. Grasas Aceites 67, e159. doi: http://dx.doi. org/10.3989/gya.0450161.

Copyright: (C2016 CSIC. This is an open-access article distributed under the terms of the Creative Commons Attribution (CC-by) Spain 3.0 License.

*This manuscript was presented in the I Workshop INSA-UB “The Universe of the Olive Oil”, in November 2015. 


\section{ROLE OF THE ARACHIDONIC ACID CASCADE ON INTESTINAL EPITHELIAL CELL GROWTH AND COLORECTAL CANCER}

Considerable amounts of arachidonic acid (AA) are found esterified at the sn-2 position of the phospholipid biomembranes. Under physiological conditions, the amount of free intracellular AA available is quite small, but numerous stimuli can induce AA release through phospholipase $\mathrm{A}_{2}\left(\mathrm{PLA}_{2}\right)$ activation. Then, AA can be metabolized by cyclooxygenases (COXs) to produce prostaglandins (PGs), by lipoxygenases (LOXs) to synthesize leukotrienes (LTs) and hydroxyeicosatetraenoic acids (HETEs), and by cytochrome P-450 pathway to produce HETEs and epoxieicosatetraenoic acids (EETs) (Figure 1). These bioactive lipids have pleitropic effects even though they were classically considered inflammatory mediators.

Today, the causal relationship between inflammation, innate immunity and cancer is more widely accepted; nevertheless, many of the molecular and cellular mechanisms mediating this relationship remain unresolved. However, there is now evidence that inflammatory mediators have a powerful effect on tumor development. Early in the neoplastic process, eicosanoids produced by the AA cascade could be powerful tumor promoters, producing an attractive environment for tumor growth and promoting angiogenesis in the intestinal mucosa (Ferrer and Moreno, 2010).

Studies in the early 1980s indicated that nonsteroidal anti-inflammatory drugs (NSAIDs) were chemo preventive in animal models of colorectal cancer (CRC). In 1991, Thun et al. reported that aspirin reduces the relative risk and mortality of CRC. Even more relevant for the clinician were subsequent studies that demonstrated that NSAID therapy can cause the regression of adenoma in patients with familial adenomatous polyposis (Koehne and Dubois, 2004). Furthermore, COX-2 is elevated in $\mathrm{CRC}$, with the subsequent increase of $\mathrm{PGE}_{2}$ and 6-keto $\mathrm{PGF}_{1 \alpha}$ levels (Moran et al., 2004). Using an elegant experimental model of CRC induced by genetic manipulation, Oshima et al. (1996) reported that COX-2 is located in the stromal component and may promote tumor growth by producing bioactive PGs that affect tumor growth in a paracrine fashion.

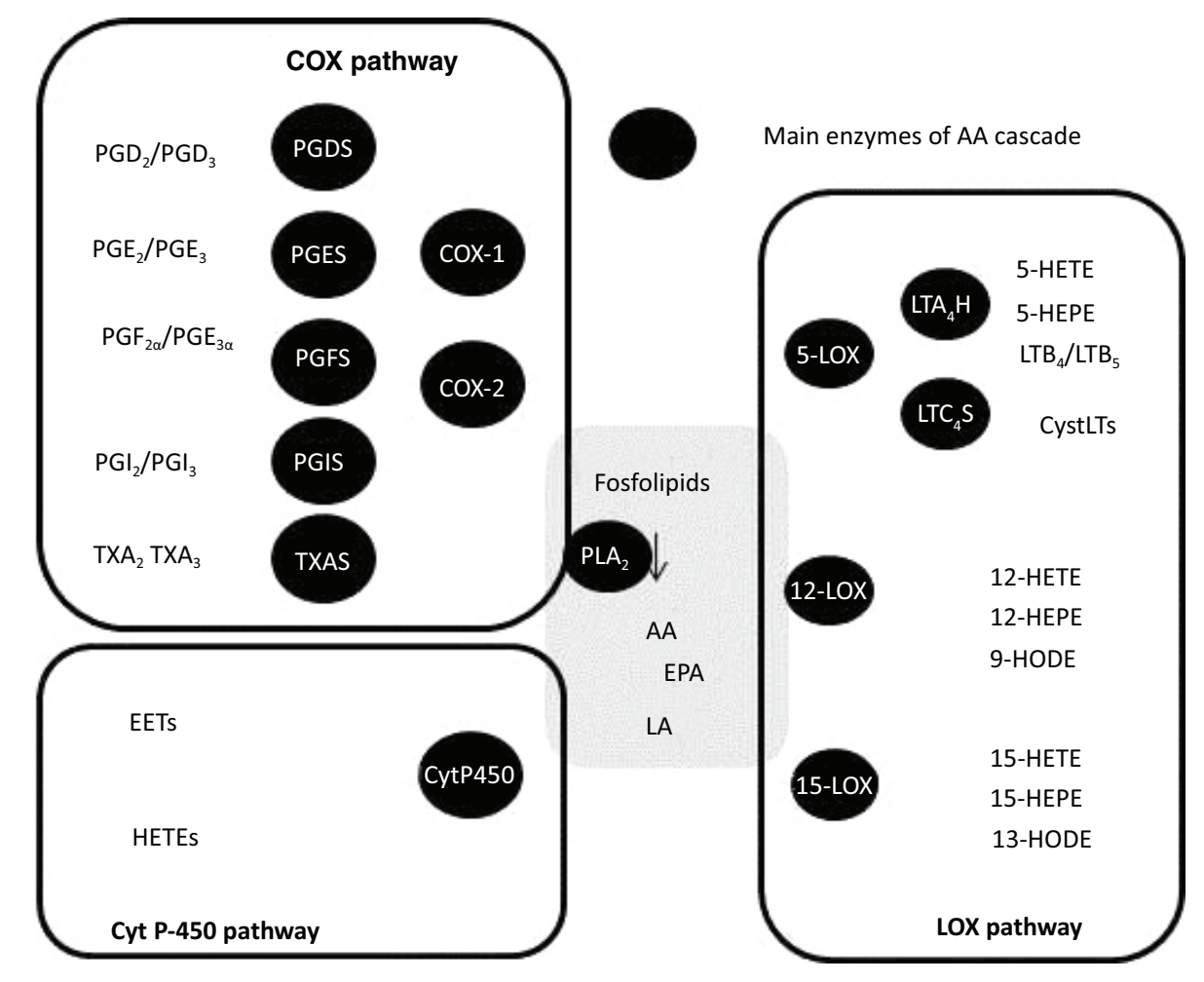

FigurE 1. Arachidonic acid cascade. This scheme illustrates the main elements of the AA cascade including the main enzymes and metabolites of cyclooxygenase (COX), lipoxygenase (LOX) and cytochrome P-450 (Cyt P-450) pathways: PGES, prost-aglandin E synthase; PGDS, prostaglandin D synthase; PGFS, prostaglandin F synthase; PGIS, prostaglandin I synthase; TXAS, thromboxane A synthase; $\mathrm{LTA}_{4} \mathrm{H}$, leukotriene $\mathrm{A}_{4}$ hydrolase; $\mathrm{LTC}_{4} \mathrm{~S}$, leukotriene $\mathrm{C}_{4}$ synthase. 
The beneficial effects of dietary manipulation of the AA content in the bio-membranes of animals that spontaneously induce polyps (APC ${ }^{\min }$ mice) suggest that AA is a key element involved in tumorigenesis (Petrik et al., 2000). Inducing a cytosolic $\mathrm{PLA}_{2}$ deletion in $\mathrm{APC}^{\mathrm{min}}$ mice, Hong et al. (2001) demonstrated the pivotal role of these enzymes involved in the AA release in small intestine polyp formation. These findings support the hypothesis that the anti-tumorigenic effects of NSAIDs are related to the impairment of PG production. However, these explanations have lacked molecular details, in largely as a consequence of a poor understanding of the role of $\mathrm{PG}$ receptors. In the last decade, important findings were obtained with respect to this point. Targeted deletion of the $\mathrm{EP}_{1}$ receptor of $\mathrm{PGE}_{2}$ reduced the number of colonic lesions in $\mathrm{APC}^{\mathrm{min}}$-induced polyp formation that was also reduced by a specific $\mathrm{EP}_{1}$ antagonist (Watanabe et al., 1999), whereas $\mathrm{EP}_{4}$ deletion reduced the tumor size. Considering all of this together, we have a complete picture of the main elements involved in the effects of the AA cascade on epithelial cell growth in physiological and patho-physiological conditions: AA is released by $\mathrm{PLA}_{2}$, then it is metabolized by COX-1/COX-2 to produce bioactive eicosanoids such as $\mathrm{PGE}_{2}$, which interact with specific receptors $\left(\mathrm{EP}_{1}\right.$ and $\left.\mathrm{EP}_{4}\right)$ and activate cell signaling pathways involved in the control of intestinal epithelial cell growth (Sanchez and Moreno, 2002; Cabral et al., 2013; Cabral et al., 2014).

Cianchi et al. (2006) reported that the two major metabolic pathways of the AA cascade, COX and 5-LOX, are simultaneously up-regulated in CRC. Interestingly, an inhibition of either COX or 5-LOX alone resulted in the activation of the other pathway, and consequently, combined treatment with COX and 5-LOX inhibitors produced greater inhibition of tumor cell proliferation. A high expression of the $\mathrm{BLT}_{1}$ receptor of $\mathrm{LTB}_{4}$ (Ihara et al., 2007) and the CystLT 1 receptor of $\mathrm{LTD}_{4}$ was detected in human colon cancer tissues, whereas $\mathrm{CysLT}_{2}$ receptor expression was reduced in colon cancer and was associated with poor prognosis, due to its capacity to induce differentiation and growth inhibition (Magnusson et al., 2007). Recently, we observed that several LOX metabolites from AA and linoleic acid such as $\mathrm{LTB}_{4}, \mathrm{LTD}_{4}$, 5-HETE, 12-HETE, 15-HETE and 13-hydroxyoctadecanoic acid are involved in the control of CRC cell line proliferation (Cabral et al., 2013; Cabral et al., 2014; Martín-Venegas et al., 2014; Cabral et al., 2015).

\section{EFFECT OF THE MEDITERRANEAN DIET AND OLIVE OIL ON COLORECTAL CANCER}

CRC is the third most commonly diagnosed cancers in developed countries, and is the second cause of cancer-related deaths. Although a great effort has been made toward developing detection and surgical strategies, there has been little improvement in the outcome for patients with advanced disease. Obviously, many elements such as the dysregulation of intestinal epithelial cell growth/apoptosis, angiogenesis and metastasis are involved in the development of CRC. Enhancement of cell proliferation is widely understood to be an important factor determining carcinogenesis. In the colon, an increased numbers of cycling cells or mitoses leading to expansion of the cell proliferation zone and increased crypt height as well as depressed apoptosis are considered risk factors for tumor development.

The traditional Mediterranean diet (MD) is widely recognized as one of the healthiest in the world and it is likely that the adoption of this diet would lead to a significant reduction in the incidence of many chronic diseases (Sofi et al., 2011). This recent meta-analysis of prospective cohort studies concluded that the MD is responsible of a significant reduction in death that included the impairment in the incidence of neo-plastic diseases. In this sense, updated reports from a large cohort such as the European Prospective Investigation into Cancer and Nutrition (EPIC) have found a lower overall cancer risk among individuals with greater adherence to the MD (Couto et al., 2011). Similar results were obtained in the large cohort belonging to the National Institutes of Health (Reedy et al., 2008).

It is the consumption of olive oil, more than any other single factor that distinguishes the traditional MD from other dietary patterns, and it has been related to the reduced risk of various neoplasms including CRC (Pelucchi et al., 2011). It is important to consider that extra virgin olive oil (EVOO) is a complex mix containing fatty acids such as oleic acid and minor compounds such as simple phenols (tyrosol and hydroxytyrosol), adhehydic secoiridoids (oleuropein), flavonoids and lignans (pinoresinol) as well as hydrocarbons (scualene), phytosterols ( $\beta$-sitosterol) and triterpenes (maslinic acid) (Table 1), and that some of these compounds may modulate the mechanism

TABLE 1. Main components of extra virgin olive oil and their daily consumption by humans

\begin{tabular}{lll}
\hline Compounds & Content & Daily consumption \\
\hline Oleic acid & $550-850 \mathrm{~g} / \mathrm{Kg}$ & $25-40 \mathrm{~g}$ \\
Linoleic acid & $50-200 \mathrm{~g} / \mathrm{Kg}$ & $2-10 \mathrm{~g}$ \\
Hydrocarbons & $1200-7500 \mathrm{mg} / \mathrm{kg}$ & $50-300 \mathrm{mg}$ \\
Phytosterols & $1800-2500 \mathrm{mg} / \mathrm{kg}$ & $100-150 \mathrm{mg}$ \\
Polyphenols & up to $1000 \mathrm{mg} / \mathrm{kg}$ & $50 \mathrm{mg}$ \\
Tocopherols & $100-300 \mathrm{mg} / \mathrm{kg}$ & $5-15 \mathrm{mg}$ \\
Triterpens & $150-1000 \mathrm{mg} / \mathrm{kg}$ & $10-50 \mathrm{mg}$ \\
Lignans & up to $100 \mathrm{mg} / \mathrm{kg}$ & $5 \mathrm{mg}$ \\
\hline
\end{tabular}


involved in the pathogenesis of CRC such as intestinal epithelial cell growth as well as apoptosis, angiogenesis and metastasis. Thus, flavonoid and lignan intakes have been inversely associated with CRC risk in several case-control studies, and The Polyp Prevention Trial Study reported that high intakes of flavonols and isoflavones were related to a decreased risk in advanced CRC. Here, we analyze the effect of oleic acid and representative EVOO minor bioactive compounds on oxidative stress, AA cascade and colon cancer cell line growth, opening the way to a more precise understanding of the molecular basis of the action of EVOO on CRC.

\section{EFFECT OF OLIVE OIL COMPONENTS ON OXIDATIVE STRESS AND AA CASCADE}

Olive oil contains a high amount of oleic acid and only a small amount of linoleic acid, the precursor of AA in mammals. Thus, olive oil provides monounsaturated fatty acids, which are not as readily oxidized as the polyunsaturated fatty acids, and consequently reduces membrane susceptibility to lipid peroxidation. Furthermore, Bartoli et al. (2000) reported that a diet rich in olive oil significantly reduced AA concentration in tissues, changes that might be responsible for the impairment of oxidative stress and the synthesis of AA metabolites (Moreno et al., 2001). There is a wellestablished inverse relationship between the dietary intake of antioxidant-rich foods and the incidence of human diseases. EVOO contains numerous minor components with antioxidant activity such as polyphenols. These facts are consistent with the observation that the minor components of olive oil protect against DNA oxidation and lipid peroxidation (Mitjavila et al., 2013). Among the minor components of EVOO, phenolic compounds are those most extensively studied. However, it should not be overlooked that EVOO contains other components that are quantitatively more significant such as hydrocarbons and phytosterols. Thus, $\beta$-sitosterol inhibits ROS production (Moreno, 2003) through the enhancement of antioxidant enzymes such as Mn superoxide dismutase and glutathione peroxidase (Vivancos and Moreno, 2005). Interestingly, polyphenols and phytosterols can modulate oxidative stress through distinct and complementary mechanisms that induce synergistic effects (Vivancos and Moreno, 2005).

We must consider that the cellular redox state may act as a molecular switch that regulates the activity of many enzymes and genes. In this way, ROS are involved in the $\mathrm{PLA}_{2}$ activation, AA release and eicosanoid synthesis (Martínez and Moreno, 2001). Consequently, foods rich in antioxidants such as EVOO modulate cellular oxidative stress, the AA cascade and reduce eicosanoid synthesis (Moreno et al., 2001), events that may be specifically modulated by bioactive components of EVOO such as polyphenols and phytosterols (Moreno, 2003; Vivancos and Moreno, 2008).

\section{EFFECT OF OLEIC ACID ON COLORECTAL CANCER AND COLON CANCER CELL LINE PROLIFERATION}

In recent decades, epidemiological data indicated a key role from the amount of dietary fat in the pathogenesis of different neoplasms as CRC (Bartsch et al., 1999). Several experimental models have also provided evidence that the fatty acid composition in the diet is a major determinant in the risk of tumor development. However, the precise mechanisms underlying their inflammatory/ anti-inflammatory, tumorigenic/anti-tumorigenic or immune-modulating effects remain largely unknown. Interestingly, dietary olive oil modulates the lipid membrane composition and the production of inflammatory mediators including PGs and nitric oxide (Moreno et al., 2001) as we mentioned above.

Olive oil has been found to have a slight protective effect on CRC development (Braga et al., 1998), while monounsaturated fat intake appeared uninfluential (Franceschi et al., 1998). Interestingly, Hansen Petrik et al., (2000) reported that $\mathrm{Apc}^{\mathrm{Min} /+}$ mice fed with an oleic acid diet presented a high number of intestinal tumors, whereas, when the diet was prepared with olive oil, Barone and co-workers (2014) observed a decrease in polyp number and polyp volume, with respect to a soybean oil diet (PUFA rich). These important discrepancies put into consideration the fact that oleic acid and olive oil can exert different effects on CRC. In this sense, we recently observed that oleic acid induces intestinal epithelial cell growth whereas oleic acid in the presence of EVOO components such as hydroxytyrosol, oleuropein, pinoresinol or maslinic acid did not have this mitogenic action (Martínez-Hovelman et al., 2013).

\section{EFFECTS OF EXTRA VIRGIN OLIVE OIL MINOR COMPONENTS ON ARACHIDONIC ACID CASCADE AND COLON CANCER CELL LINE PROLIFERATION}

Traditionally the beneficial effects of olive oil have been ascribed to its oleic acid content. However, a wide range of evidence indicates that the beneficial effects of EVOO intake are due to the minor bioactive compounds present in the unsaponifiable fraction. Thus, EVOO polyphenols such as tyrosol and hydroxytyrosol are potent antioxidants and radical scavengers (Visioli et al., 1998) that can inhibit COX pathway and the synthesis of PGs (Moreno 2003; Vivancos and Moreno 2008) as well as the synthesis 


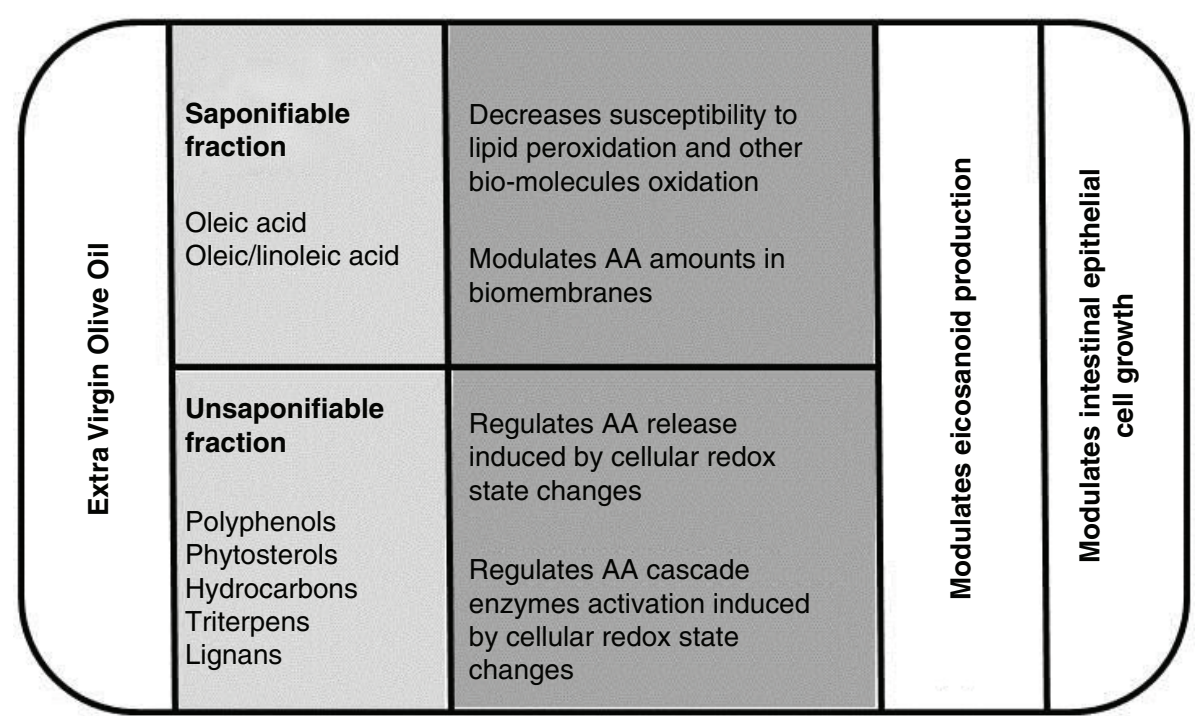

FIGURE 2. Scheme illustrating the main effects of extra virgin olive oil components on oxidative stress, AA cascade and intestinal epithelial cancer cell line growth.

of LTs by the LOX pathway (De la Puerta et al., 1999; Moreno 2003). The main phenolic compounds present in EVOO, oleuropein and hydroxytyrosol, induce a reduction in proliferation and an increase in apoptosis in human colorectal cancer cell lines by down regulating FAS activity (Notarnicola et al., 2011). In this way, we recently reported that EVOO lignans such as pinoresinol, EVOO triterpenes such as maslinic acid and EVOO hydrocarbons such as squalene inhibited cell proliferation and DNA synthesis induced by oleic acid in adenocarcinoma cell cultures (Martínez-Hovelman et al., 2013).

\section{CONCLUSIONS AND FUTURE PERPECTIVES}

In conclusion, oleic acid and oleic acid in the presence of the representative minor components of EVOO have different effects on oxidative stress, the AA cascade and intestinal epithelial cell growth (Figure 2) and consequently the consumption of seed oils, seed oils with high oleic content or EVOO will probably have different effects on CRC development. Additional research is necessary to clarify this point with important consequences for nutrition, health and economy. Furthermore, a profound clinical and experimental study on the effect of EVOO's minor components regarding CRC is also necessary to elucidate the mechanisms involved.

\section{ACKNOWLEDGMENTS}

Original research performed in our laboratory was supported by the Spanish Ministry of Science and Innovation (BFU2007-61727/BFI), by the Spanish Ministry of Economy and Innovation (AGL2013-49083-C3-1-R) and by the Autonomous Government of Catalonia (2009SGR0438 and 2014SGR0773).

\section{REFERENCES}

Barone M, Notarnicola M, Caruso MG, Scavo MP, Viggiani MT, Tutino V, Polimeno L, Pesetti B, Di Leo A, Francavilla A. 2014. Olive oil and omega-3 polyunsaturated fatty acids suppress intestinal polyp growth by modulating the apoptotic process in ApcMin/+ mice. Carcinogenesis 35, 16131619. http://dx.doi.org/10.1093/carcin/bgu068

Bartoli R, Fernández-Banares F, Navarro E, Castella E, Mane J, Alvarez M, Pastor C, Cabre E, Gassull MA. 2000. Effect of olive oil on earlyandlateevents of colon carcinogènesis in rats: modulation of arachidonicacidmetabolismand local prostaglandin E2 synthesis. Gut 46, 191-199. http:// dx.doi.org/10.1136/gut.46.2.191

Bartsch H, Nair J, Owen RW. 1999. Dietary polyunsaturated fatty acids and cancers of the breast and colorectum emerging evidence dor their role as risk modifiers. Carcinogenesis 20, 2209-2218. http://dx.doi.org/10.1093/ carcin/20.12.2209

Braga C, La Vecchia C, Franceshi S, Negri E, Parpinel M, Decarli A, Giacosa A, Trichopoulos D. 1998. Olive oil, other seasoning fats and the risk of colorectal carcinoma. Cancer 82, 448-453. http://dx.doi.org/10.1002/(SICI)10970142(19980201)82:3<448::AID-CNCR4>3.0.CO;2-L

Cabral M, Martin-Venegas R, Moreno JJ. 2013. Role of arachidonic acid metabolites on the control of non-differentiated intestinal epithelial cell growth. Int. J. Biochem. Cell Biol. 45, 1620-1628. http://dx.doi.org/10.1016/j. biocel.2013.05.009

Cabral M, Martin-Venegas R, Moreno JJ. 2014. Differential cell growth/apoptosis behaviour of 13-hydroxyoctadecadienoic acid enantiomers in a colorectal cancer cell line. Am. J. Physiol. Gastrointest. Liver Physiol. 307, G664-G671. http://dx.doi.org/10.1152/ajpgi.00064.2014

Cabral M, Martin-Venegas R, Moreno JJ. 2015. Leukotriene $\mathrm{D}_{4}$-induced Caco-2 cell proliferation is mediated by prostaglandin $\mathrm{E}_{2}$ synthesis. Physiol. Rep. 3, e12417. http://dx.doi. org/10.14814/phy2.12417 
Cianchi F, Cortesini C, Magnelli L, Fanti E, Papucci L, Schiavone N, Messerini L, Vannacci A, Capaccioli S Perna F, Lulli M, Fabbroni V, Perigli G, Bechi P, Masini E. 2006. Inhibition of 5-lipoxygenase by MK886 augments the antitumor activity of celecoxib in human colon cancer cells. Mol. Cancer Ther. 5, 2716-2726. http://dx.doi. org/10.1158/1535-7163.MCT-06-0318

Couto E, Boffeta P, Lagiou P, Ferrari P, Buckland G, Overvad K, Dahm CC, Tjønneland A, Olsen A, Clavel-Chapelon F, Boutron-Ruault MC, Cottet V, Trichopoulos D, Naska A, Benetou V, Kaaks R, Rohrmann S, Boeing $\mathrm{H}$, von Ruesten A, Panico S, Pala V, Vineis P, Palli D, Tumino R, May A, Peeters PH, Bueno-de-Mesquita HB, Büchner FL, Lund E, Skeie G, Engeset D, Gonzalez CA, Navarro C, Rodríguez L, Sánchez MJ, Amiano P, Barricarte A, Hallmans G, Johansson I, Manjer J, Wirfärt E, Allen NE, Crowe F, Khaw KT, Wareham N, Moskal A, Slimani N, Jenab M, Romaguera D, Mouw T, Norat T, Riboli E, Trichopoulou A.2011. Mediterranean dietary pattern and cancer risk in the EPIC cohort. $\mathrm{Br}$. J. Cancer 104, 1493-1499. http://dx.doi.org/10.1038/ bjc. 2011.106

De la Puerta R, Ruiz-Gutiérrez V, Hoult JR. 1999. Inhibition of leukocyte 5-lipoxygenase by phenolics from virgin olive oil. Biochem. Pharmacol. 67, 445-449. http://dx.doi. org/10.1016/S0006-2952(98)00320-7

Ferrer R, Moreno JJ. 2010. Role of eicosanoids on intestinal epithelial homeostasis. Biochem. Pharmacol. 80, 431-438. http://dx.doi.org/10.1016/j.bcp.2010.04.033

Franceshi S, La Vecchia C, Russo A, Favero A, Negri E, Conti E, Montella M, Filiberti R, Amadori D, Decarli A. 1998. Macronutrient intake and risk of colorectal cancer in Italy. Int. J. Cancer 76, 321-324. http://dx.doi. org/10.1002/(SICI)1097-0215(19980504)76:3<321::AIDIJC6>3.0.CO;2-X

Hong KH, Bonventre JC, O' Leary E, Bonventre JV, Lander ES. 2001. Deletion of cytosolic phospholipase $\mathrm{A}_{2}$ suppresses Apc ${ }^{\text {in }}$-induced tumorigenesis. Procc. Natl. Acad. Sci. USA 98, 3935-3939. http://dx.doi.org/10.1073/ pnas. 051635898

Ihara A, Wada K, Yoneda M, Fujisawa N, Takahashi H, Nakajima A. 2007. Blockade of leukotrienes $B_{4}$ signaling pathway induced apoptosis and suppresses cell proliferation in colon cancer. J. Pharmacol. Sci. 103, 24-32. http:// dx.doi.org/10.1254/jphs.FP0060651

Koehne CH, Dubois RN. 2004. COX-2 inhibition and colorectal cancer. Semin. Oncol. 31, 12-21. http://dx.doi. org/10.1053/j.seminoncol.2004.03.041

Magnusson C, Ehrnström R, Olsen J, Sjölander A. 2007. An increased expression of cysteinyl leukotriene 2 receptor in colorectal adenocarcinomas correlates with high differentiation. Cancer Res. 67, 9190-9198. http://dx.doi. org/10.1158/0008-5472.CAN-07-0771

Martin-Venegas R, Jáuregui O, Moreno JJ. 2014. Liquid chromatography-tandem mass spectrometry analysis of eicosanoids and related compounds in cell models. $J$. Chromatogr. B 964, 47-49. http://dx.doi.org/10.1016/j. jchromb.2014.05.024

Martínez J, Moreno JJ. 2001. Role of $\mathrm{Ca}^{2+}$-independent phospholipase $\mathrm{A}_{2}$ on arachidonic acid release induced by reactive oxygen species. Arch. Biochem. Biophys. 392, 257-262. http://dx.doi.org/10.1006/abbi.2001.2439

Martínez-Hovelman N, Storniolo CE, Moreno JJ. 2013. Effects of olive oil minor components on intestinal epithelial cancer cell growth induced by oleic acid. Ann. Nutr. Metab. 62, 34

Moran AE, Hunt DH, Javid SH, Redston M, Carothers AM, Bertagnolli MM. 2004. Apc deficiency is associated with increased Egfr activity in the intestinal enterocytes and adenomas of C57BL/6J-Min/+ mice. J. Biol. Chem. 279 , 43261-43272. http://dx.doi.org/10.1074/jbc.M404276200
Moreno JJ, Carbonell T, Sanchez T, Miret S, Mitjavila MT. 2001. Olive oil decreases both oxidative stress and the production of arachidonic acid metabolites by the prostaglandin $\mathrm{G} / \mathrm{H}$ synthase pathway in rat macrophages. J. Nutr. 131, 2145-2149.

Moreno JJ. 2003. Effect of olive oil minor components on oxidative stress and arachidonic acid mobilization and metabolism by macrophages RAW 264.7. Free Radic. Biol. Med. 35, 1073-1081. http://dx.doi.org/10.1016/ S0891-5849(03)00465-9

Mitjavila MT, Fandos M, Salas-Salvado J, Covas MI, Borrego S, Estruch R, Lamuela-Raventós R, Corella D, MartínezGonzalez MÁ, Sánchez JM, Bulló M, Fitó M, Tormos C, Cerdá C, Casillas R, Moreno JJ, Iradi A, Zaragoza C, Chaves J, Sáez GT. 2013. The Mediterranean diet improves the systemic lipid and DNA oxidative damage in metabolic syndrome individuals. A randomized, controlled, trial. Clin. Nutr. 32, 172-178. http://dx.doi.org/10.1016/j. clnu.2012.08.002

Notarnicola M, Pisanti S, Tutino V, Bocale D, Rotelli MT, Gentile A, Memeo V, Bifulco M, Perri E, Caruso MG. 2001. Effects of olive oil polyphenols on fatty acid synthase gene expression and activity in human colorectal cancer cells. Genes Nutr. 6, 63-69. http://dx.doi.org/10.1007/ s12263-010-0177-7

Oshima M, Dinchuk JE, Kargman SL, Oshima H, Hancock B, Kwong E, Trzaskos JM, Evans JF, Takedo MM. 1996. Suppression of intestinal polyposis in Apc delta 716 knockout mice by inhibition of cyclooxygenase 2(COX-2). Cell 87 . 803-809. http://dx.doi.org/10.1016/S0092-8674(00)81988-1

Pelucchi C, Bosetti C, Negri E, Lipworth L, La Vecchia C. 2011. Olive oil and cancer risk: an update of epidemiological findings through 2010. Curr. Pharm. Des. 17, 805-812. http://dx.doi.org/10.2174/138161211795428920

Petrik MB, McEntee MF, Chiu CH, Whelan J. 2000. Highly unsaturated (n-3) fatty acids, but not alpha-linolenic, conjugated linoleic or gamma-linolenic acids, reduce tumorigenesis in Apc (Min/+) mice. J. Nutr. 130, 1153-1158.

Reedy J, Miltrou PN, Krebs-Smith SM, Wirfalt E, Flood A, Kipnis V, Leitzmann M, Mouw T, Hollenbeck A, Schatzkin A. 2008. Index-based dietary patterns and risk of colorectal cancer: the NIH-AARP Diet and Health Study. Am. $J$. Epidemiol. 168, 38-48. http://dx.doi.org/10.1093/aje/kwn097

Sánchez T, Moreno JJ. 2002. Calcium-independent phospholipase $\mathrm{A}_{2}$ through arachidonic acid mobilization is involved in Caco-2 cell growth. J. Cell Physiol. 193, 293-298. http:// dx.doi.org/10.1002/jep. 10162

Sofi F, Abbate R, Gensini GF. Casini A, Trichopoulou A, Bamia C. 2011. Accruing evidence on benefits of adherence to the Mediterranean diet on health: an updated systemic review and meta-analysis. Am. J. Clin. Nutr. 92, 1189-1196. http:// dx.doi.org/10.3945/ajen.2010.29673

Thun MJ, Namboodiri MM, Calle EE, Flanders WD, Jr. Heath CW. 1991. Aspirin use and reduced risk of fatal colon cancer. New Engl. J. Med. 325, 1593-1596. http://dx.doi. org/10.1056/NEJM199112053252301

Visioli F, Bellomo G, Galli C. 1998. Free radical-scavenging properties of olive oil polyphenols. Biochem. Biophys. Res. Commun. 247, 60-64. http://dx.doi.org/10.1006/ bbrc. 1998.8735

Vivancos M, Moreno JJ. 2008. Effect of resveratrol, tyrosol and beta-sitosterol on oxidized low-density lipoproteinstimulared oxidative stress, arachidonic acid release and prostaglandin E2 synthesis by RAW 264.7 macrophages. Br. J. Nutr. 99, 1199-1207. http://dx.doi.org/10.1017/ S0007114507876203

Watanabe K, Kawamori T, Nakatsugi S, Ohta T, Ohuchida S, Yamamoto H, Maruyama T, Kondo K, Ushikubi F, Narumiya S, Sugimura T, Wakabayashi K. 1999. Role of the prostaglandin $\mathrm{E}$ receptor subtype $\mathrm{EP}_{1}$ in colon carcinogensis. Cancer Res. 59, 5093-5096. 